Bird Conservation International (2002) 12:1-18. (C) BirdLife International 2002

DOI: $10.1017 /$ S0959270902002010 Printed in the United Kingdom

\title{
First indications of a sharp population decline in the globally threatened Spoon-billed Sandpiper Eurynorhynchus pygmeus
}

\author{
P. S. TOMKOVICH, E. E. SYROECHKOVSKI, JR., E. G. LAPPO \\ and C. ZÖCKLER
}

\begin{abstract}
Summary
Spoon-billed Sandpiper Eurynorhynchus pygmeus is classed as globally Vulnerable, based on the only available population estimate, made in 1977, of 2,000-2,800 pairs. Surveys for breeding Spoon-billed Sandpipers were carried out in summer 2000 on the Anadyr estuary coast, the Chukotka autonomous region, Russia. Although six new breeding sites were found, only 16-17 breeding males/pairs were recorded on the northern coast of the Anadyr estuary and five males/pairs on the southern coast and more southerly lagoons. These numbers were much lower than expected, and the species was not recorded in several apparently suitable areas. Four formerly known breeding sites held only one displaying male between them. At no site was there evidence of an increasing or stable local population. Together with other indicative data these suggest a sharp decline in the population of Spoon-billed Sandpiper. The previous population size estimate obviously requires updating, both because there were some incorrect assumptions in the calculations made for the first population estimate, and also due to a recent population decline. It is likely that the current population numbers under 1,00o breeding pairs. Given that the population of this species may be substantially lower than the only previous estimate, and the evidence for a possible rapid decline in its population described in this paper, it is recommended that its IUCN status is changed from Vulnerable to Endangered. No reasons for the apparent rapid rate of decline are evident within the breeding range. "Bottle-necks" should be looked for at migration sites or wintering grounds, but currently, monitoring of the population is only possible on the breeding grounds.
\end{abstract}

\section{Introduction}

Spoon-billed Sandpiper Eurynorhynchus pygmeus is listed as Vulnerable by Collar et al. (1994) and BirdLife International (2000, 2001). The species breeds in NorthEast Asia and winters in South and South-East Asia (e.g. Howes and Parish 1989, BirdLife International 200o). Very little is known of the migration, wintering distribution and non-breeding ecology of this shorebird (Howes and Parish 1989, Tomkovich 1992a, BirdLife International 2001). Its breeding ecology, including habitat requirements, site fidelity, survival, social behaviour, timing and biology, is much better known (Dixon 1918, Portenko 1939, 1957, 1972, Leonovich, 1973, Kondratyev 1974, 1982, Kistchinski 1980, 1988, Tomkovich 1994, 1995, 1998). 
Knowledge of the breeding distribution of Spoon-billed Sandpiper is based on records accumulated during the twentieth century, which were made opportunistically, mostly during the course of general faunistic studies. General patterns in breeding distribution have been described with varying levels of precision in a number of publications (e.g. Kistchinski 1988, Howes and Parish 1989, Tomkovich 1992b, Kondratyev 1998).

Flint and Kondratyev (1977) estimated the population of Spoon-billed Sandpiper at 2,000-2,800 breeding pairs, based upon an estimate of the total extent of the species's coastal breeding habitat and the limited information available on the species's distribution. Together with immatures (one- and two-year-old birds) this would imply a total population of 6,000-8,400 birds (Tomkovich and Soloviev 2000). So far, this is the only attempt to assess the total population. Whilst this approach is useful, the breeding population estimate has never been confirmed by counts of birds outside the breeding season, or by subsequent data from the breeding grounds, and it is possible that it may have been an overestimate (Tomkovich and Soloviev 2000). Moreover, data for the northern Koluchinskaya Gulf, on the Arctic coast of the Chukotsky Peninsula, and Kresta Bay suggest a possible population decline (Tomkovich 1995, Dorogoi 1997, 2001, Tomkovich and Soloviev 2000). Further information on the breeding distribution and population is therefore needed, especially for the southern part of the breeding range, which is inadequately studied and where the "Anadyr lagoon" is claimed to be one of the most important breeding areas (BirdLife International 2001).

To address this, a survey was carried out in summer 2000 by the International Arctic Expedition of the Institute of Ecology and Evolution, Russian Academy of Sciences. The aim was to survey breeding habitats of Spoon-billed Sandpiper in a number of small to medium size river mouths as well as coastal spits in the Anadyr River estuary, and more southern lagoons between the Anadyr and Ugolnaya Bay (Beringovski Settlement), in Chukotka autonomous region of Russia. This area contains sites both formerly surveyed and never surveyed. The aims of the study were therefore (1) to assess the distribution of Spoon-billed Sandpiper in this part of its breeding range, and (2) to compare current and former numbers at selected sites.

\section{Methods}

Study area

Surveys took place mostly at Nizhneanadyrskaya (Lower Anadyr) Plain, the easternmost part of the Anadyr River valley, the largest river in Chukotka autonomous region. This plain is bordered by mountains: the Koryak Highland to the south, the Rarytkin Range to the west and the Zolotoi Range to the north, and is bisected by the large estuary of the Anadyr River. It looks like an inner sea bay and is separated from the Anadyr Bay of the Bering Sea by two long ancient spits, Russkaya Koshka and Zemlya Geka, partly overgrown with tundra. Coastal areas of the plain inhabited by Spoon-billed Sandpipers are of three main types:

(a) The northern shore of the Anadyr estuary rises gently to the Zolotoi Range, 
but there are several gravel spits and limited areas of salt marsh near the spits and small river deltas. Surveyed sites $7^{-10}$ fall within this type of landscape (Figure 1 and Table 1 ).

(b) The southern part of the Anadyr estuary is very shallow, and as a result most of the southern coast is a plain of fine, soft sediment covered with extensive salt marsh and bisected by deep muddy rivers. Spoon-billed Sandpiper breeding sites here are slightly elevated and sparsely vegetated areas, often with driftwood, at the upper edge of salt marsh near river banks (A. V. Kondratyev in litt. 2000). Sites 2-4 and 11-13 (Figure 1, Table 1) are typical in respect of this habitat.

(c) On the sea coast between the Anadyr estuary and Koryak Highland there are several large lagoons, connected to the Bering Sea by deep channels and separated from the sea by long spits of gravel and sand, partly covered with dunes and partly overgrown with tundra. Many freshwater and brackish lakes and marshes on the inner side of the spits provide a range of habitats (surveyed sites 15-19).

\section{Site surveys}

Nineteen sites were surveyed in June and July 2000 in the main study area (Figure 1, Table 1). Information about three additional sites was received from an auxiliary expedition team surveying coasts of the Mechigmenskaya Gulf, Chukotsky Peninsula, near the Bering Strait. Visits lasted from one day to one month at a site, and were made by several teams consisting of two to five people. Heavy caterpillar vehicles were used in June and early July as well as various boats in July for transporting teams between sites. Site surveys were carried out on foot, with up to $25 \mathrm{~km}$ covered in a day.

Previous descriptions of the main habitat requirements of Spoon-billed Sandpiper (e.g. Portenko 1957, Leonovich 1973, Tomkovich 1995) allowed us to visit and survey as many appropriate sites as possible. Suitability of an area for survey was based on a preliminary study of geographical maps of various scales (up to 1:100,000). Areas with lagoons, salt marshes and sand or gravel spits were considered most promising. Other habitats were also checked on the way to "promising" sites, or during other studies carried out during the expedition.

Breeding Spoon-billed Sandpipers are most obvious when they are singing in display flight (mostly early in the season) or are alarm-calling actively with young. Their presence at a site was indicated by seeing birds on the ground, or more often from first hearing the characteristic calls or songs, confirmed by sight. Field binoculars with magnifications of $8 \times, 10 \times$ and $12 \times$ were used. Nests or chicks were searched for by making observations of adults from a distance. As Spoon-billed Sandpipers are monogamous, with both parents incubating and attending young at least early in the chick-rearing period (Tomkovich 1998), records of displaying birds, pairs, nests and broods could all be considered as "breeding pairs". Locations where birds have been found were then mapped, and coordinates calculated.

Tomkovich and Soloviev (2000) have shown clearly that any direct method for counting breeding Spoon-billed Sandpipers (displaying males, pairs, nests, broods) results in some underestimation of the true local population size. Only a combination of methods, including individual recognition of colour-marked 


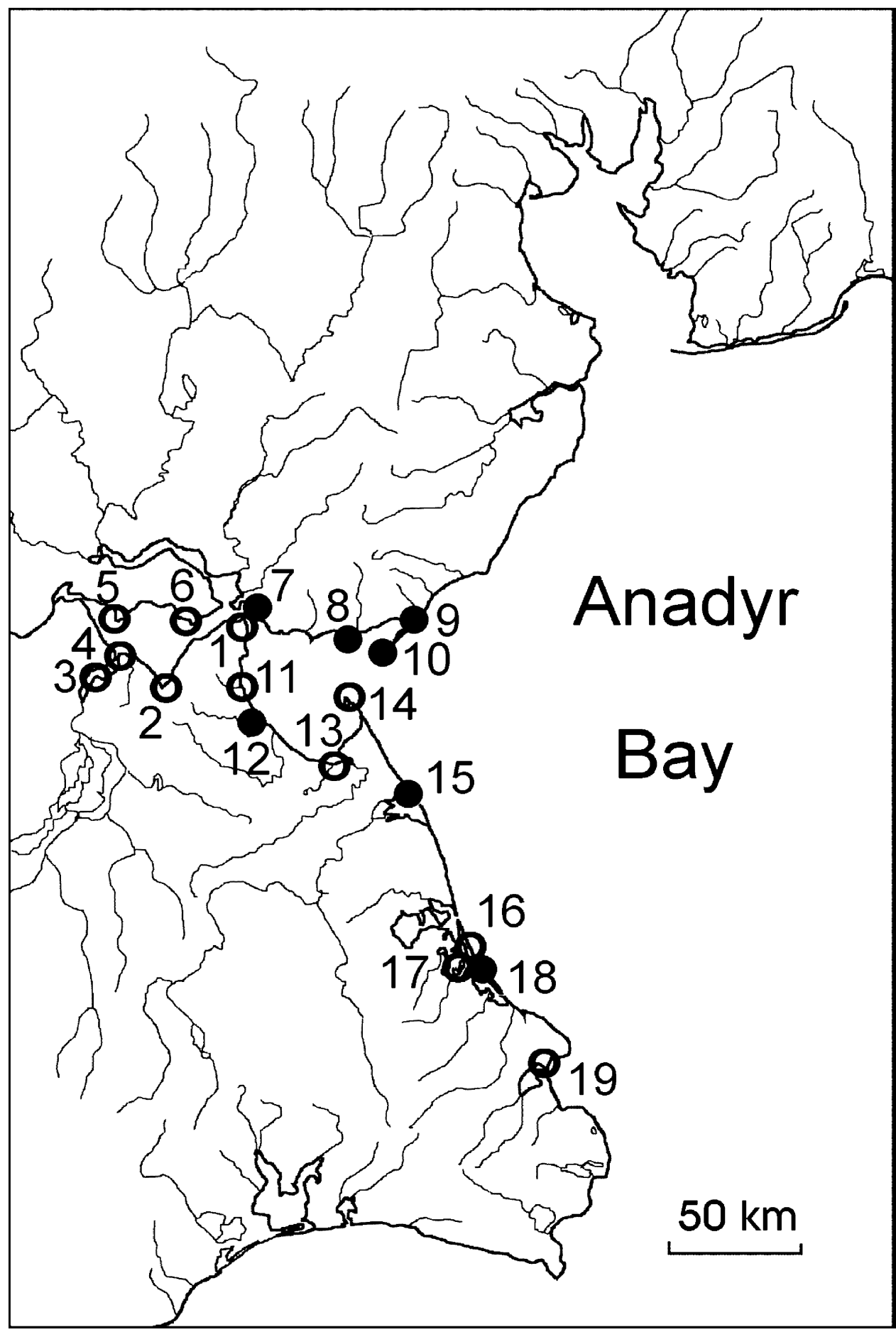

Figure 1. Study area and sites checked for Spoon-billed Sandpipers in Russia, summer 2000. Open circles, no birds found; filled circles, sites with birds. Numbers refer to sites listed in Table 1 and the Appendix. 
Table 1. Sites surveyed for Spoon-billed Sandpipers in 2000 and the main findings

\begin{tabular}{|c|c|c|c|c|c|c|}
\hline No. & Site & Date & $\begin{array}{l}\text { Number } \\
\text { of bird } \\
\text { settle- } \\
\text { ments }^{\text {a }}\end{array}$ & $\begin{array}{l}\text { Minimum } \\
\text { total } \\
\text { number of } \\
\text { adults } \\
\text { recorded }\end{array}$ & $\begin{array}{l}\text { Number } \\
\text { of } \\
\text { pairs }\end{array}$ & Comments \\
\hline 1 & $\begin{array}{l}\text { Anadyr town and } \\
\text { vicinity } \\
64^{\circ} 44^{\prime} \mathrm{N}, 177^{\circ} 31^{\prime} \mathrm{E}\end{array}$ & $\begin{array}{l}4 \text { June, } 28 \\
\text { June to } 2 \\
\text { July, 5-12 } \\
\text { July, 29 July } \\
\text { to } 8 \text { August }\end{array}$ & o & o & o & $\begin{array}{l}\text { No suitable } \\
\text { habitat } \\
\text { currently }\end{array}$ \\
\hline 2 & $\begin{array}{l}\text { Uglovaya River mouth } \\
64^{\circ} 33^{\prime} \mathrm{N}, 176^{\circ} 45^{\prime} \mathrm{E}\end{array}$ & 5-7 July & o & o & o & \\
\hline 3 & $\begin{array}{l}\text { Lower Velikaya River } \\
64^{\circ} 33^{\prime} \mathrm{N}, 176^{\circ} 10^{\prime} \mathrm{E}\end{array}$ & 8-9 July & o & o & o & $\begin{array}{l}\text { No suitable } \\
\text { habitat } \\
\text { found }\end{array}$ \\
\hline 4 & $\begin{array}{l}\text { Southern Maly } \\
\text { Onemen Bay } \\
64^{\circ} 37^{\prime} \mathrm{N}, 176^{\circ} 25^{\prime} \mathrm{E}\end{array}$ & 7 July & o & o & o & $\begin{array}{l}\text { No suitable } \\
\text { habitat } \\
\text { found }\end{array}$ \\
\hline 5 & $\begin{array}{l}\text { Kedrovaya Koshka } \\
\text { Spit } \\
64^{\circ} 48^{\prime} \mathrm{N}, 176^{\circ} 27^{\prime} \mathrm{E}\end{array}$ & 10-11 July & o & o & o & $\begin{array}{l}\text { No suitable } \\
\text { habitat } \\
\text { found }\end{array}$ \\
\hline 6 & $\begin{array}{l}\text { Cape Dlinny } \\
\text { (Bolshaya Nerpich'ya } \\
\text { Koshka Spit) } \\
64^{\circ} 46^{\prime} \mathrm{N}, 177^{\circ} 05^{\prime} \mathrm{E}\end{array}$ & 11 July & o & o & o & \\
\hline 7 & $\begin{array}{l}\text { Zhilova Koshka Spit } \\
64^{\circ} 42^{\prime} \mathrm{N}, 177^{\circ} 40^{\prime} \mathrm{E}\end{array}$ & 8-9 June & 1 & 2 & 1 & \\
\hline 8 & $\begin{array}{l}\text { Nikolai Spit } \\
64^{\circ} 38^{\prime} \mathrm{N}, 178^{\circ} 20^{\prime} \mathrm{E}\end{array}$ & 12-15 June & 2 & 4 & 3 & \\
\hline 9 & $\begin{array}{l}\text { Izvilistaya River } \\
\text { mouth } \\
64^{\circ} 39^{\prime} \mathrm{N}, 178^{\circ} 50^{\prime} \mathrm{E}\end{array}$ & 19-25 June & 4 & 13 & $7^{-8}$ & $\begin{array}{l}\text { Two nests } \\
\text { found, two } \\
\text { adults ringed }\end{array}$ \\
\hline 10 & $\begin{array}{l}\text { Russkaya Koshka Spit } \\
64^{\circ} 33^{-} 40^{\prime} \mathrm{N}, 18^{\circ} 30- \\
53^{\prime} \mathrm{E}\end{array}$ & 19-24 June & 2 & 9 & 5 & $\begin{array}{l}\text { Two nests } \\
\text { found, four } \\
\text { adults ringed }\end{array}$ \\
\hline 11 & $\begin{array}{l}\text { Pervaya River mouth } \\
64^{\circ} 29^{\prime} \mathrm{N}, 177^{\circ} 24^{\prime} \mathrm{E}\end{array}$ & 21 June & o & o & o & \\
\hline 12 & $\begin{array}{l}\text { Lower Vtoraya River } \\
64^{\circ} 22^{\prime} \mathrm{N}, 177^{\circ} 25^{\prime} \mathrm{E}\end{array}$ & 9 June-4 July & 1 & 2 & 1 & $\begin{array}{l}\text { Breeding is } \\
\text { doubtful }\end{array}$ \\
\hline 13 & $\begin{array}{l}\text { Nikitikha River mouth } \\
64^{\circ} 11^{\prime} \mathrm{N}, 178^{\circ} \mathrm{O} 2^{\prime} \mathrm{E}\end{array}$ & $\begin{array}{l}4 \text { July-5 } \\
\text { August }\end{array}$ & 0 & 2 & o & \\
\hline 14 & $\begin{array}{l}\text { Gek Cape } \\
64^{\circ} 25^{\prime} \mathrm{N}, 178^{\circ} 15^{\prime} \mathrm{E}\end{array}$ & 15 July & o & o & o & \\
\hline 15 & $\begin{array}{l}\text { Tymna Lagoon } \\
64^{\circ} 01^{\prime} \mathrm{N}, 178^{\circ} 38^{\prime} \mathrm{E}\end{array}$ & 15-16 July & 1 & 2 & 1 & $\begin{array}{l}\text { One chick } \\
\text { ringed }\end{array}$ \\
\hline 16 & $\begin{array}{l}\text { Part of southern spit at } \\
\text { Kainupilgen Lagoon } \\
63^{\circ} 26^{\prime} \mathrm{N}, 178^{\circ} 53^{\prime} \mathrm{E}\end{array}$ & $\begin{array}{l}\text { 17-19, } \\
24 \text { July }\end{array}$ & o & o & o & \\
\hline 17 & $\begin{array}{l}\text { Molchalivy island } \\
63^{\circ} 25^{\prime} \mathrm{N}, 178^{\circ} 45^{\prime} \mathrm{E}\end{array}$ & 24-25 July & o & o & o & \\
\hline 18 & $\begin{array}{l}\text { Part of northern spit } \\
\text { and of Yuzhnaya } \\
\text { Lagoon coast } \\
63^{\circ} 24^{\prime} \mathrm{N}, 178^{\circ} 54^{\prime} \mathrm{E}\end{array}$ & 20-23 July & 1 & 3 & 3 & $\begin{array}{l}\text { Two adults } \\
\text { and six } \\
\text { chicks ringed }\end{array}$ \\
\hline 19 & $\begin{array}{l}\text { Beringovsky vicinity } \\
63^{\circ} \mathrm{O} 1-03^{\prime} \mathrm{N}, 179^{\circ} 12- \\
17^{\prime} \mathrm{E}\end{array}$ & $\begin{array}{l}\text { 18-21, } 27 \\
\text { July }\end{array}$ & o & o & o & \\
\hline
\end{tabular}

${ }^{\mathrm{a}}$ Number of groups of closely spaced males, nests, broods. 
birds, gives a result close to the true number. Even spring counts of displaying Spoon-billed Sandpipers, when birds are highly noticeable, and before some have departed after nest predation, underestimate the true population by $14-28 \%$ (mean 22\%). Thus, to estimate the true population, spring count figures should be increased by c. $20 \%$. Underestimation levels later in the season depend on predation rates because failed breeders disappear from breeding grounds, and therefore the levels are unpredictable (Tomkovich and Soloviev 2000). To estimate the population number of Spoon-billed Sandpipers in surveyed areas the suggested $20 \%$ correction was therefore followed.

Eight adult Spoon-billed Sandpipers were captured on nests or near chick(s) using luchok automatic traps. These work like a mouse snap-trap, the bird being trapped with a net after it touches the trigger. Each bird was ringed with a standard aluminium numbered ring of the Moscow Ringing Centre and additionally by one Darvic "flag" of pale green colour (a colour combination indicative for Chukotka). This colour-marking was helpful in revealing additional (unmarked) birds at a site. Birds in territorial display flights were considered to be males (Tomkovich 1994). Adult birds were sexed in the hand, based on sexual differences in biometrics (Tomkovich 1991, 1992b).

\section{Results}

\section{Season characteristics}

Based on data from the local weather bureau and the impressions of local people and the authors, spring and summer 2000 were early and dry compared with the two previous years. The tundra was already over $80 \%$ free of snow on our arrival at Anadyr town on 26 May, although most lakes were still ice-bound, and ice on some large rivers remained until 12 or 13 June. In the latter dates dwarf willows Salix spp. started to bloom, sedges Carex spp. in some shallow pools became verdant, and first imago craneflies Tipulidae and midges Chironomidae emerged. South-easterly winds prevailed and little rain fell in June and July. As a result the tundra gradually became unusually dry.

Interannual variation in the abundance of rodents on the tundra (the preferred food of most terrestrial and avian predators) has a large impact on rates of predation on bird eggs. It also therefore influences the results from bird counts in the nesting and chick-rearing periods. Signs of voles and/or lemmings (winter nests, trails, toilets, and both living and dead animals) were found at all sites visited on the Anadyr plain. Their remains were also found in nests of Roughlegged Buzzard Buteo lagopus, Sandhill Crane Grus canadensis, Snowy Owl Nyctea scandiaca, and in pellets of Herring Gull Larus argentatus, and a red fox Vulpes vulpes was found carrying a bunch of lemmings (both Dicrostonyx groenlandicus and Lemmus chrysogaster) and one root vole Microtus oeconomus. Nevertheless, records of rodents were not daily at most sites, and our general impression was that the abundance of rodents was "average" or possibly lower than average for spring. However, in the Izvilistaya River catchment, including the foothills of the Zolotoi Range, numbers of small rodents were probably above average, because avian predators specializing in rodents (Snowy Owl and Pomarine Skua Stercorarius pomarinus) were found breeding there. 
Various avian and terrestrial predators of birds or their eggs were present throughout the tundra, although species composition and numbers varied. Arctic fox Alopex lagopus and red fox are usually the main predators responsible for affecting the productivity of ground-nesting birds in the tundra (e.g. Summers et al. 1998). Both species were found in most areas surveyed, but numbers were not high and their influence on bird breeding success was low. For example, of 22 wader nests of six species under observation at the Vtoraya River, only two were depredated during the study period of three weeks, and these most likely by avian predators (skuas or gulls) rather than mammals. An unusually dense population of Grey Plover Pluvialis squatarola (hatched broods and some unhatched clutches were found) at coastal spits of the Kainupilgen and Yuzhnaya lagoons also suggests that predation rates by mammals in summer 2000 were generally low.

\section{Spoon-billed Sandpiper surveys}

Within the main study area only 7 of 19 coastal sites supported breeding Spoonbilled Sandpipers (Figures 1, 2 Table 1, Appendix). Although six new breeding sites were discovered there, three of the four known sites, which had previously supported breeding populations of this species, were unoccupied in summer 2000 (Table 2). The total number of breeding Spoon-billed Sandpipers found for the northern coast of the Anadyr estuary was 16-17 males/pairs. Farther south five breeding males/pairs were found.

One more pair with a brood of chicks was found in one of three other sites surveyed on the coasts of Mechigmenskaya Gulf, east-central Chukotsky Peninsula (Appendix). This is another formerly unknown breeding site for the species.

\section{Discussion}

Spoon-billed Sandpiper is know to be a monogamous and very site-faithful species on the breeding grounds, and there are indications that even young birds have strong natal philopatry (Tomkovich 1994). Even in earlier literature, attention was paid to the constant presence of breeding birds in known very localized sites (Portenko 1972). This means that interannual fluctuations in numbers of this species apparently occur largely because of demographic reasons, rather than possible movements between sites. As a result, the number of breeding birds counted should reflect real local population sizes, not occasional ones.

\section{Numbers in the surveyed area}

An understanding of population size is important for the conservation of any species (e.g. Rose and Scott 1997). We found 16-17 breeding pairs of Spoon-billed Sandpiper along the northern shore of the Anadyr estuary and five more pairs further south to Ugolnaya Bay (Beringovsky). With an additional 20\% added to the figure (see Methods) we get a total of 20 and 6 pairs accordingly ( 26 pairs as grand total for the surveyed region). The real figure could be somewhat greater, because several breeding sites may have been missed.

This count gave especially low results for the southern portion of the region 


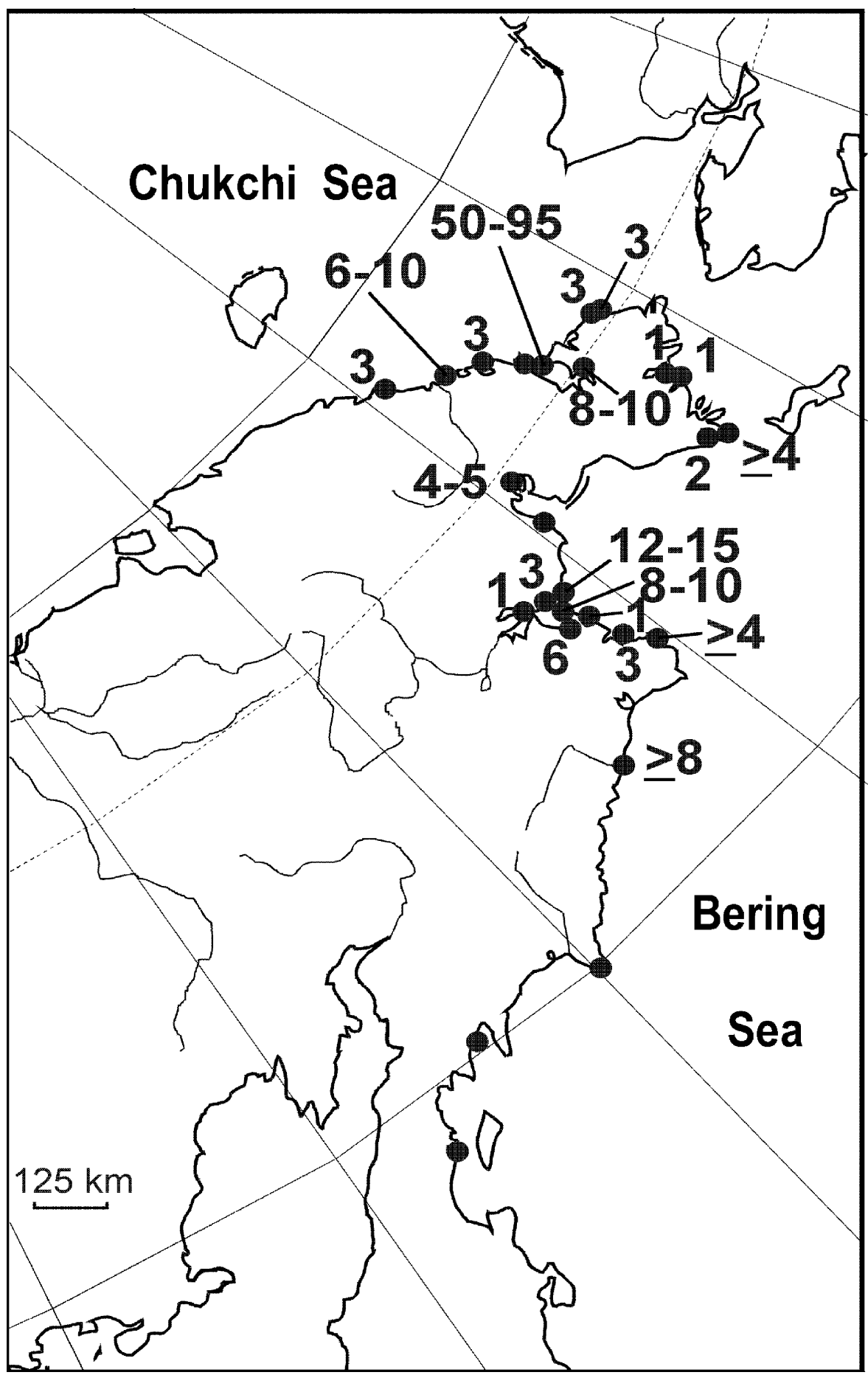

Figure 2. Spoon-billed Sandpiper breeding distribution with numbers of breeding pairs in sites when available (extraction from literature and our data). The maximum figure is given for a site if several estimates were published. 
Table 2. Historical and current breeding numbers (conservative figures) of Spoon-billed Sandpipers in revisited sites of the study region

\begin{tabular}{|c|c|c|c|c|}
\hline Site & Date and year & Number & Observation & Source of data \\
\hline \multirow{3}{*}{$\begin{array}{l}\text { Zhilova Koshka } \\
\text { Spit }\end{array}$} & 2 August 1932 & 2 & Males & Portenko 1939, 1957 \\
\hline & 1991 & 1 & Nest & Dorogoi 1993, in litt. \\
\hline & 8 June 2000 & 1 & Displaying male & This study \\
\hline \multirow[t]{2}{*}{ Nikitikha River } & $1991-1994$ & 2 & $\begin{array}{l}2 \text { pairs in mouths } \\
\text { of each small river }\end{array}$ & $\begin{array}{l}\text { A.V.Kondratyev, in } \\
\text { litt. }\end{array}$ \\
\hline & 4 July-2 August 2000 & o & Breeding birds & This study \\
\hline \multirow[t]{2}{*}{ Gek Cape } & $\begin{array}{l}\text { 17-18 July } 1933 \\
\text { late June } 1991\end{array}$ & $\begin{array}{l}8-10 \\
\text { at least } 5\end{array}$ & $\begin{array}{l}\text { Pairs with broods } \\
\text { Displaying males }\end{array}$ & $\begin{array}{l}\text { Portenko 1939, } 1957 \\
\text { A.V.Kondratyev, in } \\
\text { litt. }\end{array}$ \\
\hline & 15 July 2000 & o & Birds seen & This study \\
\hline \multirow[t]{2}{*}{ Beringovsky } & 6 August 1975 & at least 3 & $\begin{array}{l}\text { Broods of flying } \\
\text { young with adults }\end{array}$ & $\begin{array}{l}\text { Kistchinski 1980, } \\
\text { 1988, Tomkovich, } \\
\text { pers. obs. }\end{array}$ \\
\hline & 18-21, 27 July 2000 & o & Birds seen & This study \\
\hline
\end{tabular}

${ }^{a}$ Local birds, because broods dissociate before southward departure (Tomkovich 1995)

due to both an incomplete coverage and the surveying of some sites late in the breeding season when there was a greater chance that some nests and broods had been depredated. Taking into account these amendments, our expert estimate is 22-25 breeding pairs on the northern coast of the Anadyr estuary, 5-7 breeding pairs on its southern coast and 10-15 breeding pairs at lagoons between the Anadyr estuary and Ugolnaya Bay. Thus the grand total for this expert estimate is for about $380 \mathrm{~km}$ of sea and Anadyr estuary coastline.

If we consider that this number of birds inhabits approximately one eighth of the total coastline length within the breeding range of Spoon-billed Sandpiper, then the region surveyed in summer 2000 cannot be regarded as a "core area" for the species, at least currently. This conclusion is especially obvious if we compare our optimistic population estimate of $37-47$ breeding pairs for $380 \mathrm{~km}$ of coastline, with $45-51$ breeding pairs along c. $25 \mathrm{~km}$ of coastline in northern Kolyuchinskaya Gulf (in the northern part of the breeding range), in the late 1980s (Tomkovich and Soloviev 2000).

\section{Total population size}

Our survey does not allow an estimate of the total current population size of breeding Spoon-billed Sandpipers, because of an absence of adequate information from other sections of the species's breeding range. Nevertheless, based on the results of the survey in summer 2000 and an analysis of the original paper by Flint and Kondratyev (1977), it is possible to make several comments on the population estimate (2,000-2,80o breeding pairs) made by Flint and Kondratyev (1977).

Flint and Kondratyev (1977) considered for their calculations that local concentrations of breeding Spoon-billed Sandpipers varied from 2-3 to 10-15 pairs, 
most often numbering 6-8. Additionally, they suggested a number of sites where the species is more numerous, with numbers reaching 50-100 pairs, based on available observations (in the northern Kolyuchinskaya Gulf). Based on the study of maps, they also suggested the following as breeding areas supporting large numbers of birds: the western coast of Kolyuchinskaya Gulf, the coast between Russkaya Koshka Spit and Uel'kal, and "several other areas of Chukotsky Peninsula". They estimated the total number of breeding Spoon-billed Sandpiper as 1,500-2,000 pairs in small "settlements" and 500-800 in large ones.

In the Anadyr estuary area, local "settlements" of Spoon-billed Sandpipers did not exceed three pairs, with the greatest total number of birds being 12-15 pairs (as conservative and optimistic estimates, respectively) at Russkaya Koshka Spit together with the Izvilistaya site. Contrary to the opinion of Flint and Kondratyev (1977), the coast between Russkaya Koshka Spit and Uel'kal does not look suitable for breeding Spoon-billed Sandpipers according to our map study and visit (north-eastwards of Izvilistaya River mouth to the point with coordinates $64^{\circ} 43^{\prime} \mathrm{N}, 179^{\circ} \mathrm{oo}$ 'E). This coast is steep with cliffs on some stretches. During visits to various coastal sites on Chukotsky Peninsula in the 1980s and 1990s (review in Dorogoi 1997) not a single new large local population of Spoon-billed Sandpiper was found. Thus, our observations and literature review lead us to state that no sites with numbers reaching 50-100 pairs are so far known within the breeding range apart from a single area north of the Kolyuchinskaya Gulf. These new data and reasons support our assertion that the widely quoted figure of $2,000-2,800$ breeding pairs for the world population was an overestimate, even for the 1970 .

Unfortunately, it is impossible to suggest a new reliable figure for the Spoon-billed Sandpiper population until new surveys are made in other parts of the species breeding range. This is because there is inadequate knowledge of numbers in some "promising" areas and there has been a sharp population decline (as suggested by the results of this study - see below). However, based on current knowledge of the breeding distribution and numbers, collected over many decades, our preliminary estimate is of about 1,000 breeding pairs as a maximum.

\section{Indications of a population decline}

During the survey in 2000, seven new breeding sites of Spoon-billed Sandpiper were found: (six are shown on Figure 1 and one site in the Mechigmenskaya Gulf outside the main survey area). However, numbers of Spoon-billed Sandpiper counted during the survey were low, and in all four sites where the species was already known to breed, numbers were clearly lower than during previous surveys. In one of these four sites, one displaying male was recorded, and no breeding birds at all were found in three other sites (Table 2). This does not seem to be a result either of bad weather (it was an early, warm and dry summer), or of high egg or chick loss due to increased predation rates (good breeding success was recorded in other waders). In light of these findings, previous information about the population decline recorded in the late 1980s in two more northerly sites (Dorogoi 1997, 2001, Tomkovich 1995, Tomkovich and Soloviev 2000) receives added credence. Thus, the 2000 and some other recent surveys indicate 
that a rapid population decline may be taking place in different parts of the species breeding range, which needs to be further investigated by more surveys on the breeding grounds.

\section{Possible reasons for the decline}

Various reasons for such a population decline can be suggested and should be checked. Pollution was suggested as a reason for the disappearance of Spoonbilled Sandpipers near Egvekinot, south-western Chukotsky Peninsula (Dorogoi 2001). Industrial development (our observation) could have resulted in the local decline at Zhilova Koshka Spit near Anadyr airport. Heavy recreational use of the channel of Lakhtina Lagoon near Beringovsky (i.e. many summer cottages, people and dogs, pers. obs.) might force breeding birds to move. Disturbance and possibly predation by dogs may influence the local population at the tip of Russkaya Koshka spit. However, all these kinds of possible human influence are local and do not explain the decline at other sites, which are not under such pressure. Moreover, Spoon-billed Sandpipers readily breed close to human settlements. This has most probably been the case for many years, as birds were known to breed close to a settlement in Gek Cape (where remnants of ancient settlements of native people have been found; Portenko 1939, 1957), but are no longer found there, even in the absence of humans. It should also be noted that the total human population in Chukotka autonomous region declined by about half during the 1990s.

Spoon-billed Sandpiper is listed in the Red Data book of the Russian Federation (Tomkovich 2001) and officially cannot be hunted. Moreover, hunting for waders is not popular in Chukotka, and the great majority of hunters is not even aware of the existence of so peculiar a wader as Spoon-billed Sandpiper in the region. Other indirect evidence for low hunting pressure on waders in Chukotka includes the almost total absence of ring recoveries from waders in the region, in contrast to the numbers of ducks and geese recovered through hunting (data of the Moscow Ringing Centre).

Spoon-billed Sandpipers live in coastal habitats, which are attractive to wandering arctic foxes, and they exhibit a number of adaptations to a high level of predation. Nevertheless, as it was shown for the Arctic coast of Chukotsky Peninsula, predation by arctic foxes is the main factor that determines population recruitment and annual population number fluctuations in Spoon-billed Sandpiper (Tomkovich 1995). Hunting for fur of arctic fox sharply declined in the 1990s in Russia, on Chukotka in particular, but there is no clear evidence that this resulted in a general increase in the arctic fox population, nor in reducing Spoon-billed Sandpiper breeding productivity. Such a conclusion can be drawn because natural regulation of arctic fox numbers through food abundance is the main factor responsible for population fluctuations in this predator (e.g. Angerbjörn and Tannerfeldt 1995).

Population dynamics depend not only on survival on the breeding grounds and recruitment of young birds, but also on mortality during the non-breeding season. Available information regarding the situation on staging sites and wintering grounds of Spoon-billed Sandpiper is poor. No large-scale threats to the species are recognized in the Russian part of the flyway (Tomkovich 1992a). 
Farther south, intensive hunting, the increasing rate of habitat loss and other threats are apparent in many parts of coastal South-East Asia (Howes and Parish 1989, BirdLife International, 2001). To illustrate this point, a Spoon-billed Sandpiper ringed at northern Chukotka was recovered from a hunter at a Chinese market, having been taken near the Yangtze River mouth (Tomkovich 1992b). Our general impression is that unfavourable conditions at sites somewhere on the flyway or on the wintering grounds is responsible for the decline in the Spoon-billed Sandpiper population. This issue must become a matter of international concern and urgent study.

\section{Recommendations}

The main implications of this study are: (1) the global population of Spoon-billed Sandpiper is much lower than was previously thought (likely to be under 1,000 breeding pairs, or 3,00o birds), and (2) the population appears to have experienced a sharp decline in recent decades. This alarming situation has several consequences.

First, a small world population number (2,000-2,800 pairs) and a supposed population decline (inferred because of the small range, specialized breeding habitat and the various threats in both the breeding and non-breeding areas) were the reasons for classifying Spoon-billed Sandpiper as Vulnerable (Collar et al. 1994, BirdLife International, 2000, 2001). It now appears that the situation is more critical: the population is much smaller and is in sharp decline. The new evidence presented in this paper suggests that Spoon-billed Sandpiper may be Endangered, as we estimate that its total population is below 2,500 mature individuals, and its numbers appear to be in rapid decline. Consequently this wader species should be the subject of special attention by researchers and conservationists.

Second, there is an urgent need to identify any population "bottle-neck" on the flyway, for undertaking further measures to prevent extinction of this species.

Third, monitoring of the Spoon-billed Sandpiper population is necessary, and currently it is possible to do this on breeding grounds only. There is a methodology in place and population estimates for several sites to provide a baseline for such monitoring. We suggest the best sites for such monitoring are the northern Kolyuchinskaya Gulf $\left(67^{\circ} 04^{\prime} \mathrm{N}, 174^{\circ} 35^{\prime} \mathrm{W}\right)$ on Chukotsky Peninsula and the Khatyrka River delta $\left(62^{\circ} \mathrm{O} 8^{\prime} \mathrm{N}, 175^{\circ} 28^{\prime} \mathrm{E}\right)$, where high breeding numbers were formerly recorded (Kistchinski 1980, Tomkovich and Soloviev 2000). These two areas are situated in the northern and southern sections of the species's breeding range, respectively. Russkaya Koshka Spit together with the nearby Gek Cape could be a third monitoring area, which contains fewer birds but is more accessible and therefore easier and cheaper for regular visits.

Lastly, a more accurate total population estimate could be reached by further surveying of "promising" areas of the Chukotka coast, especially if combined with an inventory of Spoon-billed Sandpiper habitats based on the study of satellite images.

\section{Acknowledgements}

Financial support for the project has been received from WWF-Japan, Club '300' (Sweden), Arctic Ecology and Anthropology Centre (Moscow) and private 
sources. Japanese Wetland Action Network and personally Minoru Kashiwagi helped a lot on the early stages of the project. The Nature Conservation Committee (especially Natalia Shevchenko), the Forest Conservation Committee and the Fishing Inspection of Chukotka autonomous region were of invaluable help with logistics. Valuable help with logistics was received from Gennagy Smirnov, Vladimir and Egor Radivilov, Mikhail Shkurko, Eugeny Arkhipov, Vasily Melimuka, Sergei Kalinin, Vasily Yamanov and others. We are grateful to the expedition participants: Alexander Astapenko, Vladimir Babenko, Goetz Eichhorn, Fedor Romanenko, Chris Schenk and M. Trobitz. A. V. Kondratyev has shared with us his important information about the Anadyr estuary area and Spoon-billed Sandpiper distribution and numbers. Critical comments and suggestions of Mike Crosby, the reviewer, greatly improved the paper.

Appendix. Observations on coastal sites in Chukotka autonomous region, Russia, surveyed in summer 2000 for breeding Spoon-billed Sandpipers.

The list of 19 sites in the main study area (Nizhneanadyrskaya Plain), corresponds with those shown in Figure 1 and Table 1. Numbers 20-22 refer to observations of an auxiliary expedition team that surveyed coasts of the Mechigmenskaya Gulf, Chukotsky Peninsula.

1. During multiple excursions around Anadyr town no Spoon-billed Sandpipers were recorded. The place with best potential (mouth of the Kazachka River) is within the town, has been altered by man and does not contain the necessary habitats for nesting at present.

2. Habitats looked suitable for the species at both sides of the Uglovaya River mouth with salt marshes behind the low coastal sandy ridge. However, no birds were seen.

3. No Spoon-billed Sandpipers were found at lower Velikaya River, where river banks are mostly covered with bushes of willow(s).

4. Similar reasons might explain the absence of this bird at southern Maly Onemen Bay.

5. Kedrovaya Koshka Spit is largely overgrown with bushes of Siberian dwarf pines Pinus pumila, therefore unable to provide suitable breeding habitats for Spoon-billed Sandpipers.

6. Cape Dlinny (Bolshaya Nerpich'ya Koshka Spit) with brackish ponds and crowberry Empetrum nigrum tundra at sandy spit, seemed to be a suitable breeding site for the target species, but no birds were recorded.

7. At Zhilova Koshka Spit near Anadyr airport, one displaying male and another bird feeding with Red-necked Stints Calidris ruficollis were observed at salt marshes with numerous ditches and ponds, near the base of the spit. No birds were seen during a visit to the site the next day, which however, was windy.

8. Near the base of Nikolai Spit one pair and one displaying male were seen daily during the stay period, on tundra heavily damaged by caterpillar vehicles, several hundred metres from a patch of salt marsh and mudflats.

One male displayed at similarly damaged tundra near a creek mouth between the Nikolai and Sbornaya rivers, but the bird was absent there the next day. The species was not found on extensive salt marshes near the mouths of the Nikolai and Sobornaya rivers, which were surveyed twice. 
9. On the left bank of the Izvilistaya River mouth and the very base of Russkaya Koshka Spit three pairs were observed breeding in an aggregation. Two nests separated by a distance of $350 \mathrm{~m}$ were found on the 20 and 21 June near two rather big lakes with slightly brackish, almost fresh water. One adult each was caught on the nests. One of the nests was situated on a ridge covered by crowberry, the other nest was on a plateau at the edge of salt marsh where crowberry alternates with dwarf willows and patches of bare soil. The aggregation was at a distance of $1.5 \mathrm{~km}$ from the Bering Sea and $0.5 \mathrm{~km}$ from the lagoon near the Izvilistaya River mouth running into the Klinkovstem Bay of the Anadyr estuary.

A displaying bird was recorded on 23 June about $5 \mathrm{~km}$ further south-west, near brackish ponds at a broadening of the spit.

Several Spoon-billed Sandpipers as singles (once in a group of Red-necked Stint) were seen and/or heard near the camp site at brackish to freshwater ponds between salt marshes and a sand ridge $4 \mathrm{~km}$ upstream on the Izvilistaya River from the base of the Russkaya Koshka Spit. The maximum recorded was four on 25 June. Daily display flights by just one bird indicated one or possibly two breeding pairs.

On a one-day excursion, 25 June, five Spoon-billed Sandpipers were seen on the right bank of the Izvilistaya River mouth at salt marshes with numerous ponds and patches of tundra. Two of the sandpipers were clearly wanderers, the status of three other birds was not certain. They could be off-duty breeding birds because territorial displays of two males were observed, but the behaviour of one other bird was different. It is also possible that different observers recorded one or two of the same birds. Suitable nesting sites (tundra patches with crowberry) were uncommon in that area.

10. During the six-day survey of Russkaya Koshka Spit, which is about $25 \mathrm{~km}$ long, we discovered only a small proportion of the spit was suitable for breeding Spoon-billed Sandpipers. The spit is mostly covered by tundra with a dominance of crowberry, or by dry hillocks of gravel, or sand alternating with pebble-bottomed freshwater bodies with pebble banks. The main breeding area was at the extreme south-western end of the spit stretching c. $1.2 \mathrm{~km}$ along a ridge 3-4 $\mathrm{m}$ high, between the Hydrographic Station and fishermen's buildings. Two nests and one extra pair were found there and a possible one extra pair was breeding nearby. Four adults were captured on the nests, ringed and released.

The two nests were situated at a distance of 300 and $700 \mathrm{~m}$ from the sea, $300 \mathrm{~m}$ from the Hydrographic Station and $800 \mathrm{~m}$ apart. They were placed on plain tundra: one near a pool within $30 \mathrm{~m}$ of the beginning of the ridge, the other at the very edge of the salt marsh, $100 \mathrm{~m}$ from the mudflats of the inner bay. Between the ridge and the sea, at about $200-300 \mathrm{~m}$, there is a chain of shallow ponds both sandy and muddy bottomed, connected to the sea by a semi-dry creek.

Another area of the spit where Spoon-billed Sandpipers most probably breed is at a widening of the spit near Gedeon Cape, which was surveyed briefly on 22 June. Two displaying birds were found c. $200 \mathrm{~m}$ from each other and c. $300 \mathrm{~m}$ from the sea, where ridges covered with crowberry tundra alternate with brackish ponds. Apart from that, one feeding or passing 
Spoon-billed Sandpiper was recorded almost daily at the salt marshes of the inner bay, at the westernmost end of the spit.

11. On an excursion to the Pervaya River mouth the upper edge of an extensive salt marsh was checked both around the Pervaya River and along several creeks between the Pervaya and Vtoraya rivers. The sites looked marginally suitable for Spoon-billed Sandpipers, but none were recorded.

12. During a 24-day study at the lower Vtoraya River Spoon-billed Sandpipers were recorded only twice at almost the same place where the river runs among upper salt marshes with relatively sparsely vegetated tundra on flat elevations with driftwood along the river banks. Two birds in chasing flight were seen there over the floating river ice on 11 June, and one bird (supposedly male) on 20 June was feeding on muddy edges of a pool near the river and chasing Temminck's Stint Calidris temminckii. No birds were found in the same area in following days. Thus, an occasional breeding of one pair is possible in this area, although in both cases the birds could be strangers.

13. During a one-month stay in the Nikitikha River mouth calls of Spoon-billed Sandpiper were heard only once, on 4 July, and in addition one adult bird feeding among Red-necked Stints was seen farther west near the Indrino (Kamenka) River mouth on about 25 July. Thus, no signs of breeding were found in this area where the species is known to have bred before: display flights and birds alarming with young were recorded there at transitional tundra near the edge of salt marshes in 1991-1994 by A. V. Kondratyev (in litt. 2000).

14. At Gek Cape all the best breeding sites of Spoon-billed Sandpiper known (Portenko 1939, 1957, A. V. Kondratyev in litt. 2000) were checked on an excursion. No birds of this species were found.

15. During a survey of the northern and southern spit and a nearby island in the Tymna Lagoon, one adult Spoon-billed Sandpiper alarming with unfledged young (9-14 days old) was found and another adult bird in a flock of Red-necked Stints without any signs of breeding behaviour was observed. On both dates they were observed near the strait connecting the lagoon with the sea. The brood stayed in a typical habitat, at a site where a low and narrow sandy ridge covered by crowberry, grass and herbs separated the lagoon and salt marsh depression with pools, winding ditches and lakes. There was dry crowberry tundra on the rising slope behind the depression. At the edges of the depression low sedges with sparse dwarf willows formed a transitional belt.

16. A detailed survey of the southernmost $11 \mathrm{~km}$ of the $20-\mathrm{km}$-long southern spit, that separates the Kainupilgen Lagoon from the Bering Sea, was undertaken. The main area of the spit was covered with dry crowberry tundra or sand dunes, numerous lakes were oligotrophic and freshwater, thus the habitat was unsuitable for Spoon-billed Sandpiper. Nevertheless, salt marshes and brackish lakes neighbouring dry ridges necessary for the species to breed were also available along the lagoon side of the spit, but no Spoon-billed Sandpiper was recorded.

17. The northernmost $6 \mathrm{~km}$ of the Yuzhnaya Lagoon spit was surveyed in detail. Habitats were similar to those described for the Kainupilgen Lagoon spit, 
although salt marshes were much more extensive in Yuzhnaya. Nevertheless, no Spoon-billed Sandpiper was recorded.

On 21-23 July adult Spoon-billed Sandpipers were recorded with three broods on the isthmus between the Kainupilgen and Yuzhnaya lagoons $\left(63^{\circ} 24^{\prime} \mathrm{N}, 178^{\circ} 54^{\prime} \mathrm{E}\right)$. In fact two of them were situated at the northern shore of Yuzhnaya Lagoon ( 20 and $50 \mathrm{~m}$ from the shoreline) from which each single parent was captured and colour-marked. The third brood was originally $c$. $300 \mathrm{~m}$ from the sea and over $1 \mathrm{~km}$ from the nearest lagoon. Broods consisted of two chicks each (7.5-11 days old) and were found in an unexpected habitat. They were in gullies between tussocky hills where snowmelt was very late (in one case it was still present in late July). Because of this late snowmelt, the bottom of depressions was damp and marshy, while both bottom and lower slopes were vegetated with mosses and sparsely with various herbs, grasses, sedges and in some places with dwarf shrubs. Only guesses can be made where these Spoon-billed Sandpipers had their nests, however the broods could move big distances from hatching sites: one of the broods had moved $250 \mathrm{~m}$ in one day.

18. A large island (local name Molchalivy) in the Kainupilgen Lagoon was visited. It was hilly, composed of sand and some boulders, had lakes and secondary lagoons and was mostly sparsely vegetated. No Spoon-billed Sandpipers were found in the best-looking places.

19. Near Beringovsky, visits were paid to the northern shore of the channel connecting the Lakhtina Lagoon with the Bering Sea, where Spoon-billed Sandpipers were known to breed in 1975 (Kistchinski 1980). No birds of this species were recorded either in the former breeding site, or in other suitable sites along the channel. It deserves mentioning that the area had many summer cottages situated rather densely along the shore of the channel. People and dogs visit the best Spoon-billed Sandpiper habitats quite often; however, the situation had not worsened much in comparison with 1975 (P.S.T. pers. obs.), and broods of Ringed Plover Charadrius hiaticula, Dunlin Calidris alpina and other birds were present.

20. In the vicinity of Lorino Settlement $\left(65^{\circ} 30^{\prime} \mathrm{N}, 171^{\circ} 42^{\prime} \mathrm{W}\right)$, east of the mouth of the Mechigmenskaya Gulf, no Spoon-billed Sandpipers were found in the periods 10-18 June and 22-24 July. The spit was very "stony" and heavily disturbed by locals (with many fishing and hunting containers). The coastal tundra was marshy or rather heavily vegetated.

21. Spoon-billed Sandpipers were also not recorded near Alakynotgytgyn (Glukhoe) Lake $\left(65^{\circ} 43^{\prime} \mathrm{N}, 172^{\circ} 30^{\prime} \mathrm{W}\right)$, at the north-west end of the Mechigmenskaya Gulf between 19 June and 5 July. This area outside of any river delta contained only small salt marshes without the combination of lots of ponds and dry tundra, unlike site 22.

22. In the Utaatap River delta area, south-west of the Mechigmenskaya Gulf, during period 6-20 July only one pair of Spoon-billed Sandpiper with brood of three small downy chicks was found on 12 July between the Utaatap and Tynacynveem rivers $\left(65^{\circ} 28^{\prime} \mathrm{N}, 172^{\circ} 27^{\prime} \mathrm{W}\right)$. The brood stayed on low and flat complex tundra near the upper edge of salt marshes and about $500 \mathrm{~m}$ from the high-tide coastline. The uniform salt marsh was at a distance of $c .200 \mathrm{~m}$, but small patches of salt marsh could be found in the vicinity. The brood 
was $c .3 \mathrm{~m}$ from the nearest pond on a patch of meadow in some way similar to salt marsh. This area contained numerous small to medium size brackish ponds where a mosaic of dry tussocky tundra was interspersed with mosses, lichens and even small patches of bare soil. Two Spoon-billed Sandpipers were found alarming in the same area on 18 July, but an attempt to find chicks again failed.

\section{References}

Angerbjörn, A. and Tannerfeldt, M. (1995) Life history ecology of the Arctic Fox in Siberia. Pp. 118-121 in E. Grönlund and O. Melander, eds. Swedish-Russian Tundra EcologyExpedition-94. A cruise report. Stockholm: Swedish Polar Reserch Secretariat.

BirdLife International (2000) Threatened birds of the world. Barcelona and Cambridge, U.K.: Lynx Edicions and BirdLife International.

BirdLife International (2001) Threatened birds of Asia: the BirdLife International red data book. Cambridge, U.K.: BirdLife International.

Collar, N.J., Crosby, M.J. and Statterfield, A.J. (1994) Birds to watch 2: the world list of threatened birds. Cambridge, U.K.: BirdLife International.

Dixon, J. (1918) The nesting grounds and nesting habitats of the Spoon-billed Sandpiper. Auk 35: 387-404.

Dorogoi, I.V. (1993) Ornithological records on eastern Chukotka. Bull. Moscow Soc. Naturalists. Biol Div. 98: 16-18. (in Russian).

Dorigoi, I.V. (1997) The fauna and distribution of waders in North-East Asia. Pp. 53-87 in A.V. Andreev, ed. Species diversity and population status of nearwater birds in North-East Asia. Magadan: NESC FEB RAS. (In Russian.)

Dorigoi, I.V. (2001) Wader records in Kresta Bay and on the Amguema River, Chukotka. Ornithologia 29: 290-291. (In Russian.)

Flint, V.E. and Kondratyev, A.Ya. (1977). An experience of evaluating of total number of rare stenotopic species (Spoon-billed Sandpiper Eurynorhynchus pygmeus as an example). P. 250 in M.A. Voinstvenski, ed. 7th All-Union Ornithol. Conf. Abstracts of talks. Part 2. Kiev, Naukova Dumka. (In Russian.)

Howes, J. and Parish, D. (1989) New information on Asian Shorebirds: a preliminary review of the INTERWADER Programme 1983-1989 and priorities for the future. Kuala Lumpur, Malaysia: Asian Wetland Bureau (Publication 42).

Kistchinski, A.A. (1980) Birds of Koryak Highland. Moscow: Nauka. (In Russian.)

Kistchinski, A.A. (1988) Avifauna of North-East Asia: history and modern status. Moscow: Nauka. (In Russian.)

Kondratyev, A. Ya. (1974) To study of nesting life of Spoon-billed Sandpiper. Pp. 119-126 in F.B. Chernyavski and V.G. Krivosheev, eds. Zoological investigations in Siberia and the Far East. Vladivostok: Far-Eastern Science Center, the USSR Academy of Science. (In Russian.)

Kondratyev, A. Ya. (1982) Biology of waders in tundras of north-eastern Asia. Moscow: Nauka. (In Russian.)

Kondratyev, A. Ya, ed. (1998) Red data book of the Far East: Russia. Moscow: Penta Publishers. (In Russian.)

Leonovich, V.V. (1973) Materials for study of Spoon-billed Sandpiper. Pp. 75-77 in V.E. Flint, ed. Fauna and ecology of waders. Part 2. Moscow: Moscow University Press. (In Russian.)

Portenko, L.A. (1939) Fauna of Anadyr Land. Birds. Part I. Leningrad: Glavsevmorput. (In Russian.)

Portenko, L.A. (1957) Studien an einigen seltenen Limicolen aus dem nordichen und 
ostlichen Sibirien.1. Der Loffelschnepfe Eurynorhynchus pygmeus (L.). J. Orn. 98: 454-466. Portenko, L.A. (1972) Birds of Chukotsky Peninsula and Wrangel Island. Part I. Leningrad: Nauka. (In Russian.)

Rose, P.M. and Scott, D.A. (1997) Waterfowl population estimates. Second edition. Wageningen, The Netherlands: Wetlands International (Publ. 44).

Summers, R.W., Underhill, L.G. and Syroechkovski, E.E., Jr. (1998) The breeding productivity of Duck-bellied Brent Geese and Curlew Sandpipers in relation to changes in the numbers of Arctic Foxes and lemmings on the Taimyr Peninsula, Siberia. Ecography 21: 573-580.

Tomkovich P.S. (1991) External morphology of the Spoon-billed Sandpiper (Eurynorhynchus pygmeus) at northern Chukotsky Peninsula. Ornithologia (Moscow) 25: 135-144. (In Russian.)

Tomkovich P.S. (1992a) Migration of the Spoon-billed Sandpiper Eurynorhynchus pygmeus in the Far East of the Russian Federation. Stilt 21: 29-33.

Tomkovich P.S. (1992b) Spoon-billed Sandpiper in north-eastern Siberia. Dutch Birding 14: 37-41.

Tomkovich P.S. (1994) Spatial structure of the Spoon-billed Sandpiper (Eurynorhynchus pygmeus) population at breeding grounds. Pp. 130-148 in E.N. Kurochkin, ed. Modern ornithology 1992. Moscow: Nauka. (In Russian.)

Tomkovich P.S. (1995) Breeding biology and breeding success of the Spoon-billed Sandpiper Eurynorhynchus pygmeus. Russ. J. Orn. 4: 77-91 (In Russian with English summary.)

Tomkovich P.S. (1998) Mating system and parental care in the Spoon-billed Sandpiper Eurynorhynchus pygmeus. Russ. J. Orn., express-issue 31: 3-6. (In Russian.)

Tomkovich, P.S. (2001) Spoon-billed Sandpiper Eurynorhynchus pygmeus (Linnaeus, 1758). Pp. 504-506 in D.S. Pavlov, V.V. Rozhnov and V.E. Flint, eds. The red data book of Russian Federation (animals). Moscow: AST, Astrel. (In Russian.)

Tomkovich, P.S. and Soloviev, M.Y. (2000) Numbers of the Spoon-billed Sandpiper at the north of Kolyuchinskaya Gulf, Chukotka, and count methods for the species on breeding grounds. Russ. J. Orn., express-issue 99: 3-10. (In Russian.)

\section{P. S. TOMKOVICH}

Zoological Museum, Moscow State University, Bol. Nikitskaya Str. 6, Moscow 103009, Russia. E-mail:pst@zmmu.msu.ru

\section{E. E. SYROECHKOVSKI, Jr.}

Institute of Ecology and Evolution, Russian Academy of Sciences, Leninski Prospect 33, Moscow 117071, Russia.E-mail:rgg@eesjr.msu.ru

\section{E. G. LAPPO}

Department of Biogeography, Institute of Geography, Russian Academy of Sciences, Staromonetny Per. 29, Moscow 109017, Russia. E-mail: rgg@eesjr.msu.ru

\section{ZÖCKLER}

UNEP-World Conservation Monitoring Centre, 219 Huntingdon Road, Cambridge CB3 oDL, U.K. E-mail: chrisz@unep-wcmc.org

Received 5 April 2001; revision accepted 10 November 2001 